\title{
EXTERNALITIES, FIRM-SPECIFIC CAPITAL INVESTMENTS, AND THE LEGAL TREATMENT OF FUNDAMENTAL CORPORATE CHANGES
}

\author{
JONATHAN R. MACEY*
}

\section{INTRODUCTION}

Mergers, hostile takeovers, plant closings, and other fundamental corporate changes cause enormous disruption in the lives of everyone connected with firms that experience such events. Workers, managers, customers, suppliers, and their families are all significantly affected. Philanthropists, rival firms, and local governments also suffer significant disruption. The larger a firm is in relation to the size of the community in which it operates, the greater the disruption any such change is likely to have. So, for example, when the United States Steel Company closed two steel plants in Yonngstown, Ohio, it was accurate to note that:

Steel has become an institution in the Mahoning Valley ....

Everything that has happened in the Mahoning Valley has been happening for many years because of steel. Schools have been built, roads have been built. Expansion that has taken place is because of steel. And to accommodate that industry, lives and destinies of imhabitants of that community were based and planned on the basis of that institution: Steel. ${ }^{1}$.

This Article attempts to develop a framework for thinking about the legal treatment of various groups affected by fundamental corporate changes. In the past, no external actors had a legal right to affect the fate of a corporation, which, acting through its board of directors or shareholders, could dispose of its assets in any way it wished. ${ }^{2}$ More recently,

- Professor of Law, Cornell University. B.A., 1977, Harvard University; J.D., 1982, Yale Law School. The author thanks John Donahue and David Haddock, both of the Northwestern University School of Law, for their valuable ideas and suggestions. The author presented eartier versions of this Article in faculty workshops at the University of Iowa College of Law, the New York University School of Law, Northwestern University School of Law, and the Washington University School of Law. He is grateful for the many helpful comments made at those workshops.

1. Singer, The Reliance Interest in Property, 40 STAN. L. REv. 611, 618 (1988) (footnote and citation omitted).

2. See, eg., Charland v. Norge Div., Borg-Warner Corp., 407 F.2d 1062, 1065 (6th Cir.) (employer's decision to relocate did not infringe on employee's rights, since employee had no property interest in job), cern denied, 395 U.S. 927 (1969); United Steel Workers, Local No. 1330 v. United States Steel Corp., 492 F. Supp. 1, 9-10 (N.D. Ohio) (rejecting workers' claim to keep plant open 
however, commentators have used economic arguments about externalities $^{3}$ and contract-law arguments about detrimental reliance ${ }^{4}$ to claim that firms must recognize employees' and outside entities' right to share in decisionmaking about fundamental corporate changes. In addition, a recent wave of state statutes now regulates the takeover process. The ostensible justification for these statutes is protection of the economic and political interests of non-shareholder constituencies. 5

The recent arguments in favor of plant-closing laws and restrictions on hostile takcovers assert that non-shareholder groups suffer enormous effects from fundamental corporate changes and generally cannot protect themselves against the shocks caused by such events. While shareholders can diversify their stock holdings to protect against the negative effects of unwanted corporate changes, non-shareholders often cannot and thus remain particularly vulnerable to the dislocations caused by corporate restructuring. For all of these reasons, it is important to examine critically how fundamental corporate çlianges affect non-shareholders; such an examination will help determine whether the legal system should generate new legal rules to protect these groups.

As a starting point, it seems appropriate to assess the theoretical underpinnings of the common law's assumptions about property rights in corporate firms. In the past, common law courts and state corporate codes have analyzed fundamental corporate clianges solely from the shareholder perspective, without considering how such changes affect non-shareholder constituencies. Even though courts and legislatures have historically neglected these constituencies, commentators have drawn the conclusion that some alternative set of legal rules would serve society better than the established property-rights-oriented system does.

With respect to the external effects of fundamental corporate clianges, I beheve that the private contracting process, though not perfect, generates outcomes superior to the outcomes generated by government regulation. This is true for five reasons. First, restrictive statutes discourage corporate investinents, ultimately harming non-shareholder groups' interests. Because fundamental corporate changes are necessary to preserve shareholder wealth, to redeploy underutilized corporate assets, and to impose market discipline on poor management, regulation

based on management promises and employees' property rights), aff'd in part and racated in parth 631 F.2d 1264 (6th Cir. 1980).

3. See, eg., Coffee, Shareholders Versus Managers: The Strain in the Corporate Web, 85 MrCH. L. REV. 1 (1986).

4. See, eg., Singer, supra note 1, at 663-99.

5. See, eg., IDAHo CODE § 30-1604 (Supp. 1988); KY. REv. STAT. ANN. § 271A.397(4) (Baldwin 1988); MINN. Stat. ANN. § 302A.251(5) (West Supp. 1989); WASH. Rev. CODE ANN. $\S 23 A .50 .010$ (Supp. 1989). 
should encourage, not discourage, such changes. Dislocations to nonshareholder constituencies, while real, can best be remedied by side payinents, made through intrafirm contracts. Second, regulation in this area is likely to create significant moral hazards, causing regulatory beneficiaries to engage in inefficient behavior in an effort to inaximize their chances of gaining a legally recognizable claim against firms involved in fundamental corporate changes. Third, outcomes generated by the legislative process are likely to reflect the interests of well-organized specialinterest groups rather than the interests of society as a whole. Fourth, because fundamental corporate changes lead to a diverse set of problems, they call for the kind of particularized solutions that only private law can yield. For all of these reasons, judges and legislatures should refrain from creating innovative new inethods of helping these non-shareholder constituencies. Finally, even if the public-law systen were likely to generate rules that faithfully serve the public interest, most proponents of public-law solutions greatly overstate the extent to which such intervention helps non-shareliolder groups. Regulation forces the various contractimg parties involved with corporations to purchase certain rights and sell certain obligations, resulting in Pareto-inferior allocations within such corporations.

Modern finance theory has slown that shareliolders retain plenary authority to guide the fate of a corporate enterprise because, at the inargiu, they liave the greatest stake in the outcome of corporate decisioninaking ${ }^{6}$ and not because they hold certain ill-defined property rights. Shareholders retain the ultimate right to control corporations because they value this right more than do other groups and because it is therefore efficient for them to retain control. Indeed, contrary to popular belief, it is not particularly useful to think of corporations in terms of property rights, since the modern theory of the firm tells us that, while each participant in the corporate enterprise owns certain inputs (labor, capital, machinery, inventory), the firm itself is nothing but a web of contractual relationships ainong these various production factors. When one views a corporation in this way, the relevant inquiry becomes not who owns the corporation, but (1) whether these contractual arrangeinents make parties to the contracts better off and, if so, (2) whether these arrangements liarm third (noncontracting) parties who cannot adequately protect themselves and who, because of this harm, have legitimate claims for legal protection.

6. See Fama, Agency Problems and the Theory of the Firm, 88 J. PoL. Econ. 288, 288-89 (1980). 
As this Article shows, shareholders may sometimes seek to engage in fundamental corporate changes such as mergers and plant closings in order to transfer wealth to themselves from other parties who have claims on a firm's income stream. While most fundamental changes occur for sound economic reasons (such as the need to re-deploy underutilized corporate assets), these changes can also allow contracting parties to transfer wealth through opportunistic behavior. Such wealth transfers become possible because parties make firm-specific capital investmentsincluding human capital investments-that can be appropriated through a fundamental corporate change. This Article does not focus on whether exploitation is theoretically possible-it is. The Article instead takes up the more interesting and difficult question of which corrective mechanism-the private contracting process or the public regulatory processcan best solve the problein. The Article argues that the former choice most effectively protects the interests of parties who have contractual links with the corporation.

For organizational purposes, the Article divides persons affected by fundamental corporate changes into two groups: those with preexisting contractual relationships with a firm and those without such relationships. The Article then explores the effects these changes have on each group. It also examines each group's ability to use public law or private contracting to solve the problems presented by fundamental corporate changes. Part I describes current law as it affects the entities (shareholders, managers, workers, and creditors) within and outside the corporate web of contractual relationships. Part II describes the conflicts among parties in contractual privity with firms and shows how each party's wealth- or security-maximizing strategies exhibit those conflicts. It reviews the recently proposed legal solutions to the problems raised by fundamental corporate changes and critiques those solutions. This part also discusses contractual parties' investments in firm-specific human capital and looks at these parties' exposure to or engagement in behavior desigued to exploit their or others' firm-specific capital investments. Part III describes the problems that fundamental changes impose on parties outside a given firm and analyzes those problems in light of recent legal scholarship arguing that outside groups, such as local governments and philanthropists, should enjoy property rights in firms in which they have an interest. This part concludes that recognizing such rights would harm the very parties that the rights are supposed to protect.

\section{Current Law}

Unless there is an express, private agreement to the contrary, nonshareholder constituencies have no common law property right in a cor- 
poration. While commentators have Jamented the absence of such a right, ${ }^{7}$ no judicial authority has explicitly recognized it. ${ }^{8}$ Recently, however, courts and Congress have expressed a willingness to recognize noncontract-based interests of non-shareholder constituencies. For example, when the Denver Post faced a hostile takeover, the Tenth Circuit recognized that corporate directors had a responsibility to consider extrinsic interests in deciding whether to resist: "In this case we have a corporation engaged chiefly in the publication of a large metropolitan newspaper, whose obligation and duty is something more than the making of corporate profits. Its obligation is threefold: to the stockholders, to the employees, and to the public."9 Such judicial approval of a board's consideration lias become almost commonplace. ${ }^{10}$ As the Delaware Supreme Court has noted,

If a defensive measure is to come within the ambit of the business judgment rule, it must be reasonable in relation to the threat posed. This entails an analysis by the directors of the nature of the takeover bid and its effect on the corporate enterprise. Examples of such concerns may mclude ... the impact on "constituencies" other than shareholders (i.e., creditors, customers, employees, and perhaps even the community generally) .... ${ }^{11}$

Indeed, a federal district court has stated that "[a] corporation with a perceived threat of dismemberment of large divisions of the enterprise, employing thousands of employees, owes substantial regard for their pension benefits, and in the case of loyal manageinent, severance benefits."12 According to the court, a board of directors must balanee investor interests, on one hand, "and the legitimate concerns and interests of employees and management ... who service the interests of investors, on the other."13

7. See, e.g., Singer, supra note 1 , at $750-51$ (recognition of new property rights would protect those most vulnerable to economic change); $c f$. Block \& Miller, The Responsibilities and Obligations of Corporate Directors in Takeover Contests, 11 SEC. REG. L.J. 44, 72 (1983) (business judgment rule can provide ancillary protection to third parties' interests).

8. See, eg., Local 1330, United Steel Workers v. United States Steel Corp., 631 F.2d 1264, 1282 (6th Cir. 1980) (creation or recognition of such a right is legislative, not judicial prerogative); Charland v. Norge Div., Borg-Warner Corp., 407 F.2d 1062, 1065 (6th Cir.) (no property right in job security), cern denied, 395 U.S. 927 (1969).

9. Herald Co. v. Seawell, 472 F.2d 1081, 1091 (10th Cir. 1972); see also id. at 1094-95.

10. See, e.g., Norlin Corp. v. Rooney, Pace, Inc., 744 F.2d 255, 264-65 (2d Cir. 1984) (board must have wide latitude in its decision processes); Enterra Corp. v. SGS Assocs., 600 F. Supp. 678, 68488 (E.D. Pa. 1985) (other entities' interests can justify use of "standstill agreement" to prevent takeover); Block \& Miller, supra note 7, at 68 (idea that firms should consider social impact of their activities has gained wide acceptance).

11. Unocal Corp. v. Mesa Petroleum Co., 493 A.2d 946, 955 (Del. 1985).

12. GAF Corp. v. Union Carbide Corp., 624 F. Supp. 1016, 1019-20 (S.D.N.Y. 1985).

13. Id. at 1020 . 
Courts have failed to articulate a theoretical basis for providing extracontractual property rights in corporate assets, but commentators have explored several possibilities. In particular, Professor Singer has argued that doctrines from areas other than corporate law-such as tort law, property law, contract law, and family law-might justify establishing such rights. ${ }^{14}$

Congress has followed the courts' lead in creating new property rights for non-shareholder constituencies. For example, a controversial new statute requires that employers with 100 or more employees give sixty days' notice prior to certain layoffs. ${ }^{15}$ This bill gives some employees a new, inalienable right to certain corporate information. ${ }^{16}$

Furthermore, several state statutes allow directors of a corporation to consider how their actions affect the corporation's einployees, supphers, and customers, as well as the communities in which the corporations's facilities are located.17 A few states add that directors, in discharging their duties, may consider the economy of the state and the nation. ${ }^{18}$

In the context of the market for corporate control, Ohio requires bidders to file details about the anticipated effect of their aequisitious on employment, general economic activity, and tax revenues; other states permit boards of directors to take such factors into account when considering how to respond to an outside bid. ${ }^{19}$ Although a federal court recently held the Ohio statute unconstitutional on commerce clause grounds, ${ }^{20}$ the statute illustrates a growing trend among state legislatures to allow (or even require) corporatious to consider the interests of parties

14. Singer, supra note 1 , at 621 .

15. Worker Adjustment and Retraining Notification Act, Pub. L. No. 100-379, §§ 2(a), 3, 102 Stat. $890,890,891$ (1988) (to be codified at 29 U.S.C. $\$ 2102$ ).

16. This non-contract-based right to advance notice of layoffs also found a place in the 1988 Democratic Party platform. See Excerpts From the Democratic Platform: A Revival of Hope, N.Y. Times, July 20,1988, at A20, col. 1 ("advance notice of [layoffs] is not only fundamentally right but also economically sound").

17. See, eg., InI ANN. STAT, th. 32, para. 8.85 (Smith-Hurd Supp. 1988); IND. CODE ANN. 8 23-1-35-1(d) (Burns Supp. 1988); ME REv. Stat. ANN. tit. 13A, § 716 (1964 \& Supp. 1988); MinN. STAT. ANN. § 302A.251 (West 1985 \& Supp. 1989); Mo. ANN. STat. § 351.347 (Vernon Supp. 1989); N.M. STAT. ANN. § 53-11-35(D) (Supp. 1988); OHo REv. CODE ANN. § 1701.59(E) (Anderson Supp. 1987); 42 PA. Cons. Stat. ANN. $\$ \S 8363-8364$ (Purdon 1987); Wis. Stat. ANN. $\S 180.305$ (West Supp. 1988).

18. See, eg. MinN. Stat. ANN. § 302A.251; N.M. Stat. ANN. § 53-11-35(D); OHo Rev. CODE ANN. § 1701.59.

19. See Ohio Foreign Business Acquisition Act, No. S. 359, sec. 1, § 1710.03, 1988 Ohio Legis. Boll. 42, 43 (Anderson) (effective Feb. 12, 1988), repealed by id. secs. 2-3, 1988 Ohio Legis. Bull. at 43 (repeal in same enactment, effective July 1, 1988); see also MiNN. STAT. ANN. \$302A.251 (allowing directors to consider non-shareholder interests when they decide whether "the continued independence of [a] corporation" is desirable).

20. Campeau Corp. v. Federated Dep't Stores, 679 F. Supp. 735, 739 (S.D. Ohio 1988). 
with which they have no contractual ties. ${ }^{21}$

\section{Fundamental Corporate Changes: The Interests of Those In CONTRactual Privity With a Firm}

In classic articles that reshaped our conception of the corporate enterprise, Alchian and Demsetz ${ }^{22}$ and Jensen and Meckling ${ }^{23}$ articulated a vision of the corporation as a team of inputs organized under a set of related contractual arrangements. In 1980, Eugene Fama further advanced our understanding of the corporation when he abandoned "the typical presumption that a corporation has owners in any meaningful sense."24 In claiming that the concept of firm ownership is irrelevant, Fama observed that the large corporation's central identifying feature is separation of the inanagement function from the risk-bearing function, and he emphasized contract rather than legal metaphysics as the proper basis for understanding that structure.

Embedded within the view that a corporation is simply a net of interdependent contractual relationships is the idea that the same contracting process that creates a corporation in the first place determines the precise terms of these legal relationships. For this reason, the theory of the firm implies that the law should respect the legal arrangements accepted by those within the firm. In other words, the theory of the firm recognizes the benefits of private ordering.

As the following discussion shows, the contracting process that creates a corporation is capable of addressing the difficulties raised by the prospect of fundamental corporate change. The theory of the firm imphies that the various participants in a corporate enterprise will trade rights and obligations among themselves, taking account of their respective skills and abilities as well as the corporation's needs. Within every successful enterprise, a complex bargaining process allows rights to be "sold" to those who value them the inost. The corporation's charter, bylaws, and, to some extent, the laws of the situs in which the corpora-

21. See, e.g., KY. REV. StAT. ANN. § 271B.12-210 (4) (Baldwin Supp. 1988); MnNN. Stat. ANN. § 302A.251(5); cf. IDAHO CODE § 30-1604 (Supp. 1988) (state considers extracontractual entities and their interests when regulating business combinations); N.J. STAT. ANX. § 14A:10A-2 (West Supp. 1988) (same); TEN.: CODE ANN. § 48-35-202(2) (1988) (same); WASH. REv. CODE ANN. \$23A.50.010 (Supp. 1989) (same).

22. Alchian \& Demsetz, Productiom, Information Costs and Economic Organization, 62 AM. ECON. REV. 777,794 (1972).

23. Jensen \& Meckling, Theory of the Firm: Managerial Behavior, Agency Costs and Ownership Structure, 3 J. FN. Ecox. 305 (1976) (integrating "elements from the theory of agency, the theory of property rights and the theory of finance to develop a theory of the ownership structure of the firm").

24. See Fama, supra note 6, at 289. 
tion chooses to incorporate, reflect the precise outcome of this process. The allocation of rights and obligations will vary from firm to firm, depending on a multitude of factors, such as the various claimants' risk preferences, the contracting parties' relative bargaining power, and the nature of the expected returns on the firm's assets.

In hight of these realities, legal rules that purport to "protect" noncontracting parties from the effects of fundamental corporate cliange often simply rearrange relationships previously agreed to by the parties involved with a firm. These rules tend to reduce the overall value of firms that must comply with them. For example, if a legislature unilaterally gives rank-and-file workers a right to prior notification of a layoff or plant closing, the workers will benefit only if, to retain that right, they will not have to give up something worth more than the right itself. The price of the foreed "purchase" of a right to notification may take the form of lower wages, reduced pension benefits, or a reduction in the overall size of the workforce. Similarly, we can easily see why employees do not bargain for rights to assume control of their employers' firms when the firms become insolvent: such rights would give workers a strong imcentive to drive their employers' firms into insolvency and thus would carry a considerable cost.

From the perspective of a firm as a whole, legal rules that purport to redefine specific details of arrangements among corporate actors might make all parties worse off because such rules prevent the parties from receiving the benefits of bargains to which they had previously agreed. The law should seek to protect, rather than undermine, these contract arrangements. With respect to laws regulating fundamental corporate changes, this means that courts should (1) seek to discover the nature of the imphicit contracts among the various parties that make up a firm, (2) police ex post contractual opportunism by parties seeking to exploit the firm-specific capital investments made by others, and (3) respect the special needs of shareholders as residual claimants.

While all interested parties might appear to bear the risk that a corporation will do poorly, sbareliolders are unique because they hold variable claims to a firm's imcome stream. Unlike bondholders and employees, shareholders do not negotiate compensation schedules in advance of performance. Rather, shareliolders bear the costs of abnormally good or bad corporate performance because they receive compensation only after fixed claims are paid. ${ }^{25}$

The differing interests of fixed claimants and sliareholders inevitably lead to conflict. In assessing how the legal system should deal with fun-

25. Easterbrook \& Fischel, Voting in Corporate Law, 26 J.L. \& EcoN. 395, 403 (1983). 
damental corporate changes, we must take up the delicate task of determining the nature of the implicit contract between fixed claimants and shareholders.

\section{A. Intrafirm Conflicts and the Implicit Corporate Contract}

The most important manifestation of the conflict of interest between fixed claimants and shareholders hes in their attitudes toward the optimal level of risk that a firm should take. ${ }^{26}$ Shareholders have a powerful incentive to induce their firms to engage in activities that fixed claimants would consider excessively risky. ${ }^{27}$ This is because shareholders stand to reap all of the benefits from the spectacular success of a particularly risky activity, but stand to lose only the amount of their initial capital investment. ${ }^{28}$ Fixed claimants, in contrast, do no better when their firm performs very well than when their firm garners only a moderate return. ${ }^{29}$ For this reason, shareholders generally retain the right to control inost details of a firm's business, subject to the broad contractual protections that fixed claimants extract to protect themselves against default.

As Professor Coffec has recently pointed out, this conflict between shareholders and fixed claimants becomes even inore acute when a firm is on the brink of insolvency. ${ }^{30}$ In such cases, shareholders will gain nothing froin the returns on a conservative investment, which fixed claimants alone will enjoy. The shareholders will prefer investments that are "much riskier" but offer the "possibility, albeit remote, of a bonanza pay-

26. Jensen \& Meckling, supra note 23, at 334-35.

27. This is not meant to suggest that shareholders always prefer risky investments to conservative ones, or that shareholders as a group have a greater tolerance for risk than do fixed claimants as a group. Rather, within the confines of any particular firm, shareholders will prefer that the firm assume greater levels of risk than will fixed claimants. As Cliff Smith and Jerold Warner have observed:

If a firm sells bonds for the stated purpose of engaging in low variance [i.e., lowi-risk] projects and the bonds are valued at prices commensurate with that low risk, the value of the stockholders' equity rises and the bondholders' claim is reduced by substituting projects which increase the firm's variance rate.

Smith \& Warner, On Financial Contracting: An Analysis of Bond Covenants, 7 J. Fr. Ecos. 117, 118-19 (1979) (footnotes omitted) (describing various mechanisms that fixed claimants use to control this conflict through intrafirm contracting process); see also W. KIEIN \& J. CoFFEE, BLSINESS Organization and Finance: Legal and Economic Principles 25-30 (3d ed. 1988) (illustrating shareholders' and fixed claimants' conflicting risk preferences and observing that "[f]rom any starting point, holding the total market value of the firm and of all securities constant, a decision that shifts investments in such a way as to increase... risk will result in an increase in the value of the common and a decrease in the value of the bonds").

28. For a useful numerical example of how shareholders can shift wealth to themselves from fixed claimants such as bondholders, see W. KLEIN \& J. COFFE, supra note 27, at 26-27.

29. Shareholders' ability to diversify their investments exacerbates the conflict between shareholders and fixed claimants.

30. Coffee, supro note 3 , at 61 . 
off that will prevent insolvency." 31

The potential policy problem, of course, is that shareholders will, using their control over a corporation, shift resources from safe investments to risky investments in order to transfer wealth from fixed claimants to themselves. ${ }^{32}$ Shareholders sometimes use fundamental corporate changes to increase risk in this way. Such restructuring consistently leads to increased debt levels, and this leverage not only increases firm risk, but also increases shareholders' appetite for risk. ${ }^{33}$ The imcreased number of fundamental corporate changes in recent years has benefitted shareholders at the expense of managers, an important species of fixed claimants. The fact that shareholders have an incentive to effectuate such transfers suggests a need for intrafirm contracting devices to mitigate this potential problem. ${ }^{34}$

Rational fixed claimants should recognize that, from their perspective, shareholders' risk-taking proclivities are excessive. When managers price a new bond issue or other form of fixed claim, fixed claimants will make judgments about the expected behavior of equity claimants and adjust the price they pay for their fixed claims to compensate themselves for the prospect that shareholders will make subsequent wealth transfers. ${ }^{35}$ Thus, shareholders, not fixed claimants, will internalize the costs of any anticipated excessive risk taking.

The structure of the large, publicly held firm prevents shareholders from increasing firm risk. Managers of such firms have economic interests in their firms that are analogous to the interests of other fixed claimants. Managers receive much of their compensation in fixed payments; they thus wish to avoid risk in order to preserve the expected value of their fixed claims. Although parties could design managerial compensa-

31. Id

32. See Smith \& Warner, supre note 27, at 118-19. The exchange of low-risk assets for highrisk assets does not decrease a firm's overall value as long as the combined net present value of all assets held by the firm remains the same. Note, however, that "stockholders will have incentives to purchase projects with negative net resent values if the increase in the firm's variance rate from accepting those projects is sufficiently large. Even though such projects reduce the total value of the firm, the value of the equity rises." Id at $119 \mathrm{n.4;}$ see also Macey \& Miller, Bank Failures, Risk Monitoring and the Market for Bank Control 88 CoLuM. L. REv. 1153, 1162-65 (1988) (explaining shareholder/fixed claimant conflict as it affects fixed claimants who are depositors in federally in. sured banks, and showing bow shareholders of such banks can transfer wealth to themselves by causing banks to shift to investments that not only increase variance but also decrease banks' overall value).

33. Costs of failure increasingly fall on fixed claimants as firm leverage increases.

34. Of course, developing such intrafirm contracts involves costs, and shareholders and fixed claimants will have an incentive to write contracts that constrain shareholders only as long as the expected gain from such contracts exceds the transaction and information costs associated with the contracting process.

35. Smith \& Warner, supra note 27 , at 119. 
tion plans to align the interests of shareholders and managers, ${ }^{36}$ such plans would fail to solve these managerial risk-avoidance problems. As Irwin Friend and Larry Lang argued in a recent article, the desire of managers to reduce both the volatility of share prices and the likelihood of insolvency motivates capital structure decisions. ${ }^{37}$ Specifically, Friend and Lang studied 984 pubhicly or closely held firms whose stock traded on the New York Stock Exchange between 1979 and 1983.38 Friend and Lang found that high levels of debt (and hence greater risk) correlated with high levels of inanagerial stock ownership. Similarly, firms whose principal stockholders were not inanagers tended to assume greater levels of risk. ${ }^{39}$ These findings agree with other empirical work showing that management-controlled firms retain a higher percentage of earnings than other firms. ${ }^{40}$ Higher retained earnings, of course, give managers and other fixed claimants greater security.

Managers' investinent preferences also differ froin shareholders' because inanagers' investments, unlike shareholders', are largely nondiversifiable. Managers' investments come in the form of human capital allocations $^{41}$ and thus diversification is impossible: managers work for only one firm at a time. This difference makes it particularly costly to write contracts that effectively link management and shareholder interests about risk taking. ${ }^{42}$ Thus, shareholders have few means of protect-

36. Cf. E. LAzEAR, Incentive Contracts (1986) (National Bureau of Economic Research Working Paper No. 1917) (discussing various ways for employers to induce an employee to work effectively).

37. Friend \& Lang, An Empinical Test of the Impact of Managerial Self-Interest on Corporate Capital Structure, 43 J. Fn: 271, 272 (1988).

38. Id. at 280 .

39. Id.

40. Williamson, Managerial Discretion and Busines Behavior, 53 Ax. ECON. REV. 1032, 104751 (1963).

41. See Coffee, supra note 3 , at $17 \&$ n.42.

42. Stock ownership, stock option plans, and compensation plans that link management compensation with firm performance all serve to align shareholders' and managers' interests. See Easterbrook, Managers' Discretion and Investor' Welfare: Theories and Evidence, 9 DEL. J. CORP. L. 540, 557-62 (1984). Easterbrook points to empirical studies showing: (1) that "for the top managers of the largest firms, the after-tax value of . . stock-based compensation was three to five times the after-tax value of . . . other compensation," id. at 559; (2) that stock-based compensation dominated other forms of remuneration for the managers of 29 large conglomerates in 1970-1975, id. at 560; and (3) that "about 65 percent of the variance in total executive compensation can be explained by differences in the firms' return on assets," id. at 561. But see Coffee, No Exit?: Opting Out, the Contractual Theory of the Corporation and the Special Case of Remedies, 53 BROOKLYN L. REv. 919, 944 (1988) (citing working paper by Michael Jensen and Kevin Murphy shoring that "the typical chief executive officer's salary plus bonuses changes less than two cents for every thousand dollar's change in the equity value of the firm").

It is relatively easy to devise managerial compensation plans that link managerial compensation to firm performance. Such plans can cause managers' time horizons for decisionmaking to coincide better with shareholders' time horizons for evaluating their investments, can reduce the incidence of 
ing themselves other than by discounting the price they pay for shares of firms in which managers own hittle stock. ${ }^{43}$ This solution to the managerial risk-avoidance problem, however, impedes the capital formation process.

Fundamental corporate changes reflect a inarket-based solution to the problein of excessive risk-avoidance. In particular, "bust-up" takeovers, financed by junk bonds, imcrease the leverage of target firms, increase risk, and benefit shareholders. ${ }^{44}$ Soine commentators, particularly Professor Coffee, have recognized this phenomenon and have condemned it:

[T]he hostile takeover can be seen not simply as a mechanism that compels management to accept that level of business risk that shareholders deem appropriate, but as a means by which shareholders outflank the safeguards managers obtained to protect the promises of deferred compensation and job security that shareholders have given to managers. Thus, what appears from the bidder's perspective to be a process of purging organizational slack looks froin the manager's viewpoint more like deceptive reneging on the original understanding. ${ }^{45}$

managerial shirking, and can reduce the costs of renegotiating managers' contracts. Smith \& Watts, Incentive and Tax Effects of Executive Compensation Plans, 7 AUsTL. J. MGMr. 139, 144-47 (1982).

Managers' excessive risk aversion makes it far more complicated, however, to devise a compensation strategy that aligns shareholders' and managers' interests. The studies cited by Easterbrook all increase rather than decrease the portion of managerial human capital that is linked to firm performance ex ante. As a consequence, while these compensation arrangements may give managers an incentive to avoid shirking in some respects, they make firm failure more costly to managersboth in terms of actual costs and in terms of opportunity costs.

To put it another way, any mechanism for aligning managers' and sliareholders' preferences for risk taking would have to provide compensation for managers who invest in projects that fail. The managerial compensation plans described above reward managers for investing in projects that succeed. While there may be benefits to shareholders who compensate managers who invest in projects that fail, there are costs as well, and, at least so far, shareholders are taking the view that the costs of writing such contracts outweigh the benefits.

Managers can diversify their human capital investunents by engaging in conglomerate inergers. Commentators have argued that such inergers were popular in the 1960s and 1970s because manag. ers were attempting to gamer the benefits of diversification. See Amihud \& Lev, Risk Reduction as a Managerial Motive for Conglomerate Mergers, 12 BELL J. ECON. 605, 605 (1981).

43. Cf. W. McEachern, Managerial Control and Performance $39-50$ (1975) (review. ing several studies showing that firms with a separation of share ownership and managerial control will have lower return on investunent than firms that shareholders control); Baumol, Heim, Malkiel \& Quandt, Efficiency of Corporate Investment: Reply, 55 REv. ECON. \& STATS. 128, 131 (1973) (firms had extremely low rates of return on projects financed through retained earnings). As Professor Coffee has pointed out, these studies indicate that managers are "overly biased toward earnings retention." Coffee, supra note 3 , at 22.

44. See Lipton, Corporate Governance in the Age of Finance Corporatism, 136 U. PA. L. REv. 1, 11 (1987). Increasing leverage increases residual claimants' expected rate of return. It also increases the variance of expected outcomes, and thus increases firm risk. W. KLEIN \& J. COFFEE, supra note 27 , at 285-86.

45. Coffee, supra note 3 , at 24 . 
This perspective assumes that shareholders have somehow promised managers that they will refrain from engaging in excessive risk taking and that fundamental corporate changes such as takeovers are thus nothing but postcontractual opportunism by shareholders. These assumptions are untenable. Once managers know that a firm "ha[s] entered the era of the two-tier, front-end-loaded, bootstrap, bust-up, junk-bond takeover," 46 they can demand compensation packages that protect them from the vagaries of the market for corporate control. In other words, the argument that managers somehow deserve protection from takeovers that imcrease firm risk makes sense only if managers are unaware that the market for corporate control can cause a firm's capital structure to reflect shareholder interests. Once managers have that information, they ought to be able to forge protective agreements with shareholders. Shackling the market for corporate control when managers and shareholders have the same information about the possibility of takeovers will only lead to misallocations of investment capital and inefficient capital structures.

Thus, the only inanagement groups who potentially deserve protection are those who erroneously took their positions while thinking that they would be able to engage in risk-avoidance strategies that would decrease their firms' expected earnings below the level of similar firms who have either a high proportion of institutional shareholders or heavy insider holdings. Yet, even this expectation seeins unreasonable, because over time one would expect such firms to founder in competitive markets because of higher costs. This fact leaves it unclear whether the legal system should respect managers' expectations that they can enjoy the benefits of risk avoidance at shareholders' expense, simce managers have an overarching duty to inaximize their firm's value for shareholders.

The theory that managers can legitimately expect to avoid risk becomes even more dubious when we look at the costs of risk avoidance. The current takeover boom stems from a gross disparity between the stock values and the asset values of U.S. firms. ${ }^{47}$ This disparity has enabled bidders to offer shareholders in target companies substantial average premiums-for exainple, $33.6 \%$ in 1986 -over current market prices. ${ }^{48}$ It is simply inconceivable that managers and shareholders would agree that managers' job security is worth over a third of the value of every firm in America.

The fact that takeovers have long been a part of corporate life makes the notion that shareholders have imphicitly agreed to give managers pro-

46. Lipton, Takeover Abuses Mortgage the Future, Wall St. J., Apr. 5, 1985, at 16, col. 4.

47. Coffee, supra note 3 , at 8.

48. Jarrell, Brickley \& Netter, The Market for Corporate Control: The Empirical Evidence Since 1980, J. ECON. PERSP., Winter 1988, at 49, 52. 
tection froin takeovers doubly implausible. For example, in the 1960s, prior to the passage of the Williams Act, America experienced a massive takeover wave. 49 Since that wave, managers have seen the takeover or restructuring of numerous eompetitiors, supphiers, and customers; this information justifies holding managers responsible if they have failed to negotiate employment contracts to compensate thein for the possibility of takeover.

Indeed, even if managers could not have anticipated the possibility of fundamental corporate changes, their lack of foresight should not empower them to obstruct new mechanisms that enhance shareholder wealth. The implicit contract between shareliolders and managers establishes that managers have a duty "to make corporate decisions so as to maximize the value of [their] company's shares."50 This widely recognized point stems from the fact that shareholders are residual claimants to an enterprise's value. ${ }^{51}$ Thus, the argument that fundamental corporate changes reflect a "deceptive reneging" 52 on the original contract between shareliolders and managers is a problematic one. The better argument is that, while the inarket for corporate control "benefit[s] shareholders," it also "mak[es] life inore uncoinfortable for top level executives" who are not satisfying the implicit terms of their employment agreements with shareliolders. ${ }^{53}$

The law should permit managers to negotiate employment agreements that compensate them for increased risks. Golden parachutes, or severance contracts that compensate managers if they lose their jobs in the event of a change in control, allow managers to obtain protection against such changes. They reduce the conflict of interest between sharelolders and managers during takeovers and permit the liuge gains associated with such fundamental corporate changes to be realized. ${ }^{54}$ The value of golden parachutes is clear: firms that provide managers with such benefits enjoy an average increase of approximately three pereent in share value. 55 In addition, a wealth of einpirical evidence shows that compensation packages that tie managerial performance to share prices

49. Romano, The Future of Hostile Takeopers Legislation and Public Opinion, 57 U. CIN. L. REv. 457, 458-60 \& tbl. 1 (1988) (correlating antitakeover laws with increased antitakeover activity).

50. R. Clapk, Corporate Law 17-18 (1986).

51. Id at 17, 18; see also supra text accompanying note 25 .

52. See Coffec, supra note 3, at 24.

53. Jensen, Takeopers: Their Causes and Consequences, J. EcoN. PERSP., Winter 1988, at 21, 45.

54. Id at 39.

55. See Lambert \& Larcker, Golden Parachutes, Executive Decision-Making, and Shareholder Wealth, 7 J. ACCT. \& ECON. 179, 19495 (1985) (securities performance of firms sampled over 16day period). 
and other measures of firm performance are common. ${ }^{56}$ These contractual provisions compensate managers for the possibility that they will lose their jobs through corporate restructuring.

Because no secondary market in managerial einployment contracts exists, information on how fundamental corporate changes affect the value of such contracts is hard to obtain. As mentioned above, however, managers' interests resemble those of fixed claimants such as bondholders, whose interests are actively traded in the financial markets. ${ }^{57}$ If fundamental corporate changes do not transfer wealth from bondholders to shareholders, they seem extremely unlikely to transfer wealth from managers to shareholders, simce managers are better able than bondholders to negotiate with shareholders. Unlike other fixed claimants, managers can renegotiate their compensation packages every year. In addition, managers control the corporate proxy machinery and, through it, the board of directors. These powers put managers in a better position than other fixed claimants to protect themselves from opportunistic shareholders who try to increase firm risk.

By observing the effect of takeovers on the value of fixed financial claims such as bonds, we can assess the argument that corporate control transactions adversely affect managers. Einpirical evidence indicates that takeover activity does not harm fixed claimants; imdeed, some groups of fixed claimants actually benefit from such activity. ${ }^{58}$ For example, a

56. See Antle \& Smith, An Empirical Investigation of the Relative Peformance Evaluation of Corporate Executives, 24 J. ACCT. REs. 1 (1986); Benson, The Self-Serving Management Hypothesis: Some Evidence, 7 J. Accr. \& EcoN. 67, 82 (1985); Coughlan \& Schmid, Executive Compensation, Management Tumover, and Firm Peformance: An Empirical Investigation, 7 J. Accr. \& EcoN. 43, 43 (1985); Murphy, Corporate Peformance and Managerial Remuneration: An Empirical Analysis, 7 J. ACCT. \& ECON. 11, 20-22 (1985); Murphy, Incentives, Learning and Compensation: A Theoretical and Empirical Investigation of Managerial Labor Contracts, 17 RAND J. ECON. 59, 60-64 (1986); P. Kostiuk, Executive Ability, Corporate Performance, and Managerial Income (May 1986) (prepared by Center for Naval Analysis, Alexandria, Va.).

57. See supro text accompanying notes $36-42$.

58. Not all intrafirm transactions benefit fixed claimants. The recent increase in large leveraged buyout transactions (such as the $\$ 17.7$ billion deal announced by RJR Nabisco in September, 1988) caused dramatic declines in bond prices. See Winkler, Harris, Williams Cos to Offer Bonds with "Poison Puts," Wall St. J., Nov. 16, 1988, at C1, col. 1. These transactions dramatically increase the amount of debt held by the firms that engage in them. This increase in leverage increases firms' risk levels and raises the probability of defauit, thereby lowering the market value of such firms' previously outstanding bonds. The reduced equity cushion brought about by these leveraged buyouts places further downward pressure on the value of the bonds.

But, consistent with the arguments presented in this Article, market forces have been quick to formulate a response to this new phenomenon. Proposed new debt issues, such as the $\$ 100,000,000$ in debentures to be offered by The First Boston Corporation and Salonon Brothers on behalf of Northwest Pipeline Corporation, have included so-called "poison put" provisions, which contain covenants that effectively protect holders of the debentures from the increased risk associated with leveraged buyouts. Northwest Pipeline Corp., Prospectus 15-16 (Nov. 1988) (on file in offices of the Duke Law Journal). These poison put provisions require the company to either: (1) redeem the 
study of 132 mergers that took place between 1962 and 1980 showed that holders of merging firms' convertible and nonconvertible preferred stock, as well as holders of convertible bonds, actually gained from such transactions. 59 Other fixed claimants, such as holders of nonconvertible bonds, neither gain nor lose from fundamental corporate changes. This point is consistent with another study showing that fixed claimants can contract to protect themselves from shareholders' opportunism. ${ }^{60}$ Bondholders can also protect themselves by buying shares and by diversifying their debt portfohos. Fixed claimants thus can use contractual devices for dealing with shareholders' atteinpted wealth transfers. If bondholders can protect themselves from the possibility that shareholders will goad firms into taking excessive risks, managers ought to be able to do so as well.

\section{B. Investments in Firm-Specific Human Capital}

While managers can easily protect themselves from shareholders' tastes for high levels of risk, the inability of managers, workers, customers, and suppliers to diversify their firm-specific capital investments poses a far heavier burden on the contracting process. Commentators, particularly the ubiquitous Professor Coffee, have argued that transactions such as hostile takeovers represent shareholder appropriation of firm-specific investments that are made by a firm's managers, workers, cnstomers, and supphiers. ${ }^{61}$

Appropriation of a firm-specific capital imvestment stems froin the existence of an appropriable quasi-rent. ${ }^{62}$ Appropriable quasi-rents arise

debentures at 100 percent of their outstanding principal amount within five days of the occurrence of a "designated event" and a "qualifying downgrade"; or (2) adjust the interest rate paid to the debenture holders in a manner that will compensate them for any increased risk when there is a designated event and a qualifying downgrade. Id.

A "designated event" consists of: (1) a merger or transfer of all or substantially all of the firm's assets to another firm; (2) any change or exchange of a majority of the common stock of the company; (3) any purchase or acquisition by any person of $30 \%$ or unore of the firm's common stock; (4) a purchase by the firm or one of its spabsidiaries of $30 \%$ or more of its own common stock; or (5) a similar transaction at the holding company level. Id. A "qualifying downgrade" occurs if the rating on the bonds by Standard \& Poor's Corporation is at least BBB twenty days prior to the occurrence of a designated event, and subsequently falls to less than BBB, or if the rating on the bonds by Moody's Investors Services, Inc. is at least Baa3 twenty days prior to the occurence of a designated event and subsequently falls to less than Baa3. Id. at 16.

59. Dennis \& McConnell, Corporate Mengers and Security Returns, 16 J. FIN. EcoN. 143, 185 (1980).

60. Smith and Warner, supra note 27.

61. Coffee, supra note 3, at 24. Coffee's arguments are confined to managers' investment of firm-specific human capital, but his argument can easily be extended to include other parties with contractual interests in a firm undergoing a fundamental corporate change.

62. The classic treatment of this subject is Klein, Crawford \& Alchian, Verical Integration, Appropriable Rents, and the Competitive Contracting Process, 21 J.L. \& EcoN. 297, 299 (1978). 
when an asset is so specialized to a particular user, or so expensive to remove, that even if the asset's owner could arrange a sale of the asset at a reduced price, high costs would prevent the owner from transferring the asset to other users. ${ }^{63}$

Klein, Crawford, and Alchian illustrate the notion of a firm-specific capital investment with an example from the automobile industry. ${ }^{64}$ They poimt out that the giant presses used for stamping out auto body parts are customized to the design and engineering specifications of particular cars. After customization takes place, manufacturers of these presses are unable to sell the enormously expensive devices to other firms. In addition, buying these presses involves a huge initial (sunk) cost but only a small imcremental (operating) cost. The danger, then, is that an auto manufacturer will act opportunistically by reneging on its initial contract to buy a press from a press owner. The auto manufacturer could do this by feigning some reason to renegotiate the contract, such as claiming that the auto industry is depressed. ${ }^{65}$ Such behavior is difficult for courts to detect. If an auto manufacturer were inclined to engage in such behavior, it might pay the owner of the press only for the small marginal costs of operating the press and appropriate the press owner's huge sunk investment in the original construction of the press. On the other hand, if the auto manufacturer could not find an alternative source for body parts, the press owner might be able to exploit the auto manufacturer. ${ }^{66}$

This section of the Article examines the opportunities for such exploitative behavior at various levels of a corporation experiencing fundamental corporate cliange. Managers, bondholders, suppliers, customers, and rank-and-file workers all face risks of expropriation, since all of them make firm-specific capital investments.

1. Corporate Management and Bondholders. A corporate employee nrakes a firm-specific liuman capital investment when he invests time and energy acquiring the job skills and training that apply only to his firm. In addition, firns may have unique patterns of communication "necessitat[ing] that special interpersonal skills be acquired to function in individual corporate environments." 67

Corporate nıanagers make such firm-specific human capital investments in their firms. But the existence of such investments does not inev-
63. Id.
64. Id. at 308-10.
65. $I d$.
66. Id.
67. Coffee, supra note 3 , at $17 \mathrm{n} .42$ (citations omitted). 
itably give shareholders opportunities to exploit managers. In fact, given that such firm-specific investments enhance shareholder wealth, shareholders may not have any greater potential for committing exploitive conduct than managers have.

Suppose, for example, that a manager sets out to obtain techmical skills or communication abilities that will be specific to her firm. Suppose further that these firm-specific skills will increase the value of her firm by $\$ 1,000,000$. Bargaining between the manager and the firm will allocate this $\$ 1,000,000$ between firm and manager. If the manager and the firm sphit the gains fifty-fifty, the manager receives an increase in pay with a present value of $\$ 500,000$, and the value of the firm's shares increases by a total of $\$ 500,000$ (if we assume that there are 500,000 shares outstanding, the value of each share will increase by $\$ 1.00$ ). Such a situation gives shareholders or outside bidders no opportumity to exploit the manager who makes this investment.

If the manager is fired, the firm's value will decline by $\$ 500,000$ : the firm will gain $\$ 500,000$ by firmg the inanager, because a replacement can be hired for $\$ 500,000$ less, but the firm will lose the $\$ 1,000,000$ increase in value that the manager's investment brought to the firm, resulting in a net decline of $\$ 500,000$. Thus, because firing the inanager and locating a replacement involves substantial costs, shareholders or acquirers of the firm are not likely to fire her. In addition, if the firm has already paid the manager some of the promised $\$ 500,000$, it will not be able to recoup this sum when it fires her. As a consequence, as time goes on and the manager has captured a larger and larger portion of the payınents owed to her for making her investment, the firm's incentive for firing her declines.

If the firm's payments to the manager track the increases in the firm's value, then the manager will be able to exploit the firm, since if she quits, the firm's value will decline by the full $\$ 1,000,000$, while the manager will still capture the full value of her investments. The limiting case is where the manager gets her entire $\$ 500,000$ as soon as she finishes making her human capital investment. In this ease, she can threaten to leave, and, since she has already captured all of the mcrease to which she is entitled, the firm has no way of retaliating against her. Thus, shareholders or tender offerors can exploit a manager who has made a firmspecific human capital investment only when the inanager has inade such an investment but has not yet received compensation for it.

Such situations may not arise very often, and it is not obvious why managers cannot contract to protect themselves from such exploitation. Just as firms and bidders can appropriate firm-specific huinan capital investments made by managers, so too can managers appropriate the payouts that firms make in exchange for such investments. Indeed, 
shareholders probably need this protection more than managers do. Because managers should fully understand the increase in firm value that comes as a result of their investments, as well as the importance of the timing of those investments, they should be able to extract ex ante promises from their firms to compensate them for the investments they make. ${ }^{68}$

2. Customers and Suppliers. The arguments made above for managers and bondholders apply with even greater force to fixed claimants such as customers and suppitiers. These parties can structure their contractual relationships with firms to solve the problem of shareholders' opportunistic behavior. Customers and suppliers make firm-specific investments not only in the form of human capital, but also in the form of fixed capital investments in specialized assets. As Klem, Crawford, and Alchian point out, however, long-term contractual arrangements (up to and including outright vertical integration) can eradicate the threat of postcontractual opportunisin by eitler party. ${ }^{69}$

3. Rank-and-File Workers. While it might seen that the probleins faeed by rank-and-file workers matcli those faeed by managers, important differences exist. Unlike high-level managers, who make firmspecific liuman capital investments as individuals, rank-and-file workers are often trained as groups and inake firm-specific liuman capital investments simultancously witl their co-workers. This arrangement contains additional potential for exploitation, because firms enjoy economies of scale in hiring and training workers. ${ }^{70}$ Suppose, for example, that teleplione operators for a particular plione coinpany require certain specialized skills, and that the phone company trains 100 unskilled workers for 50 positions. The workers' opportunity cost during their training time is $\$ 7.00$ per hour (their alternative wage as unskilled laborers), and their marginal value to the phone coinpany after their training is $\$ 25.00$ per lour. Suppose further that these workers require a one-year training period, during which they are paid only $\$ 5.00$ per hour, with a promise of

68. A large investment in human capital may result in only a negligible payoff for the firm in which it is made. In such cases, the firm will be able to "exploit" managers by firing thein before fully compensating them for their human capital investments. But even here, it is not at all obvious why intrafirm contracts cannot handle the risk that the human capital investunent will not produce tangible benefits for the firm.

69. Klein, Crawford \& Alchian, supra note 62, at 300, 302.

70. See Schleifer \& Summers, Breach of Trust in Hostile Takeovers, in Corporate Takeovers: CAuses AND CoNSEQuences 33, 41-42, 49 (A. Auerbach ed. 1988) (arguing that raiders can exploit inphicit long-term contracts between workers and managers by eliminating the inanagers committed to the contracts and breaching them so as to effect a transfer of contract wealth from workers to shareholders). 
receiving an hourly wage of $\$ 12.50$ at the end of the training period. At the end of the training period the phone company can exploit the workers by forcing them to renegotiate their contracts. The workers may be inclined to settle for some amount less than the $\$ 12.50$ they were originally promised (but greater than the $\$ 7.00$ opportunity cost of their time), because they recognize that the $\$ 2.00$ per hour in earnings they have given up during their training period is sunk. If, as might be expected, the initial promise of the higher salary is contingent on a positive evaluation of each worker by the company, the possibility of exploitation becoines palpable.

This scenario has prompted commentators to argue that takeovers and other fundamental corporate changes come at labor's expense. ${ }^{71}$ The following subsections show that neither theoretical analysis nor empirical evidence supports this argument.

a. The theoretical analysis Takeovers, bankruptcy, and other fundamental corporate changes have been widely criticized as a method of exploiting workers by forcing them to renegotiate their contracts. ${ }^{72}$ An employer's need to maintain its reputation in its community and to attract new workers in the future will tend to discourage this sort of exploitation. In addition, as a theoretical matter, workers can solve this problem by forming a union to ensure that they will not be treated opportunistically. If, in the above example, a union gives workers the ability to appropriate the capital investinent made by the phone coinpany, those workers no longer face the additional problems created by the collective nature of their training, and we return to the bilateral situation described above. ${ }^{73}$ In this context, the legal system need only protect the terms of contractual arrangements to which parties have previously agreed. In addition, firms' ability to exploit unions does not clearly exceed unions' ability to exploit firms. For both entities, the threat of a loss of reputation from refusals to act in good faith provides a strong incentive to refrain from opportunistic behavior. ${ }^{74}$ Beyond these generahities,

71. See id at 42-43. Recent takeovers in the airline industry have seemed particularly vulnerable to this argument. See Jarrell, Brickley \& Netter, supra note 48, at 57.

72. See, eg., 3 D. Cowans, BankRuptcy LaW and Practice $\S 20.13$, at 326 (1987) (in 1970s, airlines attempted to repudiate collective bargaining agreements by "running" to bankruptcy court); Comment, From Legislation to Constemation: Has Seetion 1113 Really Changed Bildisco?, 12 DEL. J. CORP. L. 167, 167-68 (1987) (prior to enactment of § 1113, union officials feared onslaught of ersatz bankruptcies to terminate unwanted collective bargaining agreements); Note, Rejection of Collective Bargaining Agreements Under the Bankruptcy Amendments of 1984, $71 \mathrm{~V}_{\mathrm{A}}$. L. REV. 983, 987 (1985) (bankruptcy procedures permitting unilateral termination of collective bargaining agreeinents allow employer to commit unfair labor practices).

73. See supro notes $64-66$ and accompanying text.

74. Klein, Cranford \& Alchian, supra note 62, at 314. 
particular problems require detailed (and costly) contractual solutions.

Public-law solutions prove unsuitable in this setting, because each case presents unique problems. Consider, for example, a statute proscribing "appropriation of firm-specific human capital investments of any type." Applying such a statute would present problems in identifying the investinents made in individual cases and in determining whether the party making those imvestments was compensated according to the original contract. Courts would face the difficult task of distimguishing ex post contractual opportunism from legitimate renegotiations im light of unforeseen circunistances.

The closing of steel mills in Youngstown, Ohio, presents a wellknown example of a fundamental corporate change and its effects. An employee union and the city of Youngstown sued to prevent the United States Steel Corporation froin closing two mills. ${ }^{75}$ The above discussion indicates that a key issue in the case should have been whether employees had made a firm-specific human capital investment in the mills-an investment that they could not have easily transferred to another job. $\mathrm{Ab}$ sent such a human capital investment, U.S. Steel should have had no incentive to engage in exploitative behavior. In cases where such investments exist, however, courts should be sensitive to the possibility of opportunistic behavior by plant owners. ${ }^{76}$ The presence of a union, however, should mitigate appropriation of workers' firm-specific investments.

Duncan Kennedy has argued that the Youngstown case was wrongly decided and that the court should have conveyed the plant to the umion "in trust for the present workers."77 Kennedy asserts that the eniployees failed to bargain for and obtain a provision turning the plant over to them because they "nriscalculated their true interests" on the basis of "particularly imperfect information."78 Obviously, if the corporation had made actual or implied promises to keep the plant open, the case sliould have come out differently. ${ }^{79}$ But Kennedy's assumption that

75. Local 1330, United Steel Workers v. United States Steel Corp., 631 F.2d 1264 (6th Cir. 1980).

76. An example of an opportunistic plant closing would be where a plant opner has several plants, all of which have workers who have made firm-specific capital investments in the respective enterprises. Such an employer could attempt to renegotiate all the workers' wages and could close one of the plants to make his threats to the workers at the surviving plants more credible.

77. Kennedy, Distributive and Paternalist Motives in Contract and Tort Law, with Special Refer. ence to Compulsory Terms and Unequal Bargaining Power, 41 MD. L. REV. 563, 630 (1982) (court should have implied such a "conveyance" term in every contract between the coinpany and individual workers).

78. Id.

79. See Farber \& Matheson, Beyond Promissony Estoppel: Contract Law and the "Invisible Handshake," 52 U. CHI. L. REV. 903, 939-42 (1985) (arguing that this may have been the case). 
a firm would grant workers ownership rights in the event of insolvency is preposterous; such an agreement would give workers an incentive to drive their employers' firms into insolvency. Kennedy's argument has these additional flaws: (1) he fails to recognize how his proposed legal rule would affect workers at other firms, and (2) he fails to recognize the sinultaneity-of-performance problems in such cases-problems that suggest workers can protect themselves from opportunistic behavior by negotiating compensation packages, rather than by lobbying for plantclosing rules.

On the subject of inultifirm effects, David Shapiro has pointed out that plant-closing rules pose

just one more deterrent to investment in domestic plant and equipment[, which] might lead to a net loss for both employers and employees. And unless the term were muposed on a nationwide basis, any state that opted for it might find itself unable to compete for new investment with other, less creative states. A nationwide rule, of course, might have a similar effect on our ability to compete with foreign suppliers. ${ }^{80}$

As Shapiro points out, although inposing paternalistic contract terms on employers might benefit particular workers, such terms harm workers in other firms, since employers will be less willing to open new facilities if legislatures or courts prohibit such employers froin closing other plants as the terms of extant contracts allow them to do.

Einployers and unions have good reasons to agree that, despite workers' inability to diversify their firm-specific human capital investments, employees should share the risk that business failure will lead to a fundamental corporate change such as inerger or bankruptcy. The workers' commitinent to success can make or break a firm. Giving workers an incentive scheme that makes them indifferent to the success or failure of a firm is irrational.

Kennedy's argument also fails to recognize that, in the event of jobthreatening fundamental corporate changes, workers will generally prefer to receive coinpensation in the form of wages rather than control of a plant. ${ }^{81}$ Since workers cannot diversify their capital investments, they will prefer to receive assets that are not linked to the firms in which they have already invested so inuch of their human capital. ${ }^{82}$

80. Shapiro, Courts, Legislatures, and Paternalism, 74 VA. L. REv. 519, 560 (1988).

81. Workers who receive wages can take this money and invest it in firms whose expected earnings are negatively correlated with the earnings of the firms for which they work, thereby reduc. ing the risk associated with their firm-specific capital investments. Workers who obtain compensation in the form of an inalienable property interest in their firm cannot diversify even to this limited extent. (1986).

82. Doernberg Macey, ESOPs and Economic Distortion, 23 HARV. J. ON LEGIS. 103, 133-36 
Similarly, workers and employers who enter into agreements that require workers to make firm-specific human capital investments face problems of imcertainty and problems relating to non-simultaneity of performance. ${ }^{83}$ These problems suggest that rational workers will not prefer to receive compensation in the form of property rights in the firm for which they work. Uncertainty arises because neither workers nor a firm can be certain of the size of the payoff from workers' human capital investments. Small investments may result in large increases in the value of firms; large investments may lead to only negligible payoffs. This uncertainty gives rise to opportunistic behavior by both sides. Workers are subject to exploitation both if they are not compensated for their human capital investments when they make the investments and if the investments do not produce positive returns. Plant-closing or similar rules that do not result in payments to corporate employees until they have already completed their human capital investments do not serve workers' interests, because such rules subject workers to exploitation during the period after their investment is complete and before plants are closed.

b. The empirical evidence. Consistent with the theoretical arguments presented above, the scant empirical evidence does not support the argument that labor suffers from hostile takeovers. Brown and Medoff's study of takeovers in Michigan shows that although employment in firms involved in acquisitions decreases, wages annually increase ${ }^{84}$

While takeovers do not generally result in a loss of jobs for rankand-file workers, some fundamental corporate changes, such as plant closings, do cost workers their jobs. The question to ask, however, is whether rules regulating plant closings will result in fewer workers being hired in the first instance-a harm arguably greater than losses of existing jobs. ${ }^{85}$ Unfortunately, measuring the extent to which regulation such as plant-closing laws diminishes employment is difficult. At least one state has passed such a law and later let it expire. ${ }^{86}$ One reason why

83. See supra notes $70-71$ and accompanying text.

84. Brown \& Medoff, The Impact of Firm Acquisitions on Labor, in CORPORATE TAKEOVERS: CALSES AND CONSEQLENCES, supra note 70, at 9; see also Macey, State Anti-Takeover Legislation and the National Economy, 1988 WIS. L. REV. 467, 478 ("spin-off transactions generally do not result in loss of jobs for rank-and-file employees because new firm owners rarely liquidate subsidiaries and fire the enployees").

85. See Shapiro, supra note 80 , at 560 (discussing the costs that plant-closing rules may impose on workers).

86. Eg. Mich. CoMp. LAWS ANN. $\$ 450.755$ (encouraging employers to give notice of decisions to close or relocate) (West 1989) (lapsed, pursuant to id. $\$ 450.759$ (i), July 2, 1984). But see id. $\S 445.601$ (unlasful for company to relocate or abandon facility without restoration of benefit and interest given by city or town); see also Califormia Attomey Discusses Trends in At-Will Employment. Torts, and ADR, DAILY LABOR REP. (BNA) No. 52, at A-7 (Mar. 20, 1989) ("[S]tates are looking at 
the plant-closing law may have expired is because such laws may deter firms from locating plants in a state, tend to increase costs, or imcrease the perception of costs, of doing business in a particular locale. This analysis suggests that plant-closing laws do not benefit workers and casts suspicion on the recently enacted federal law that requires advance notification of plant closings. 87

The critical issue raised by these plant-closing laws is not whether they benefit workers, but whether they benefit workers more than they harm other groups, particularly shareholders, who have contractual or quasi-contractual claims on firms' income streams. If such laws do not benefit workers more than they harm other groups, then workers will ultimately suffer, because affected firms will hire fewer employees.

There are several reasons to beheve that these statutes decrease shareholders' welfare by more than they increase workers' welfare. A firm on the brink of failure can sometimes experience an unexpected turnaround. The probability of such a change of fortune will drop if, after learning of a plant closing, workers disrupt the firm's activities when they leave to look for other jobs. In addition, workers as a group will be absolutely better off without advance notification of a plant closing if the benefits of notice are lower than the costs, which take the form of a higher probability that the plant at issue will in fact close. ${ }^{88}$ Simi-

plant closing legislation . . . e eighteen plant closing bills were introduced during 1988 . . . and the trend will continue. Nine states now have laws relating to plant closings and/or plant relocations.").

87. The new law, the Worker Adjustment and Retraining Notification Act, Pub. L. No. 100379,102 Stat. 890 (1988) (to be codified at 29 U.S.C. $\$ 2102$ ) requires that, under virtually all condi. tions, firms with 100 or more workers give workers and communities 60 days' notice prior to closing a plant. The bill requires that workers be paid for every day that they are deprived of notice although the bill provides exceptions for businesses struck by unforeseen circumstances and businesses in dire financial straits. See Wehr, Reagan Bows to Politics on Plant-Closing Bill, 46 CoNG. Q. WEEKIY REP. 2216, 2216 (1988).

88. A simple hypothetical clarifies this point. Suppose a firm has 10 workers. If the workers are not given 60 days' notice of a proposed plant closing, a $10 \%$ chance exists that the firm will remain open for an additional 12 months. The present value of the 10 workers' combined salarj for that $\mathbf{1 2 - m o n t h}$ period is $\$ 250,000$, or $\$ 25,000$ per worker. This $\$ 250,000$ sum must be inultiplied by the $10 \%$ probability of receiving that amount to obtain the value to the workers of not being notified of the proposed plant closing. The value to the workers is $\$ 25,000(\$ 250,000 \times .10)$, or $\$ 2500$ per worker. If the workers are given 60 days' notice, however, the probability of the plant ultimately closing declines from $10 \%$ to $5 \%$ because of the costs associated with workers seeking new jobs and leaving prematurely. Thus, the expected value of the chance that the firm will remain open for an additional 12 months declines to $\$ 12,500(\$ 250,000 \times .05)$, or $\$ 1250$ per worker. Under these circumstances, a plant-closing law will cost workers $\$ 1250$ ( $\$ 2500$ minus $\$ 1250$ ). This cost will be offset to the extent that soine workers start new jobs within the 60-day period, but the workers rould not be irrational if they agreed to decline to receive advance notice of a plant closing if declining notice would reduce the probability that the firm would close.

Under this hypothetical, after the workers learn of a plant closing, they face a collective-action problem akin to a prisoner's dilemma. Cf. Wiley, Reciprocal Altruism as a Felony: Antitrust and the Prisoner's Dilemma, 86 MICH. L. REV. 1906, 1915-16 (1988) (explaining prisoner's dilemma). They 
larly, even if it is entirely certain that a plant will close after sixty days, costs to the firm (such as reduced worker morale and higher absenteeism) may exceed the benefits to workers. This comparison of costs suggests that if workers could "sell" their entitlement to plant-closing notification back to firms, workers might come out ahead.

Finally, the new federal plant-closing law may harm workers by increasing the marginal value of locating plants overseas, beyond the reach of such laws. This law may not affect the behavior of many domestic corporations, since for most domestic firms the cost/benefit calculation about whether to locate a plant overseas is so clear-cut that the plantclosing law will not be a decisive factor. The rule will, however, have a greater effect on foreign firms that are indifferent between opening a new plant in the United States or opening it elsewhere. This effect stems not only from the direct costs of the new law, but also because passage of the law sends a signal that the U.S. government tends to pass laws that restrict firms' frcedom of action.

\section{Fundamental CoRporate Changes: The INTEREsts of OUTSIDE GROUPS}

Part II has shown that, despite the firm-specific capital investnents of bondholders, managers, custoiners, suppliers, and rank-and-file workers, fundamental corporate changes do not harm these groups, because of their ability to contract in response to the problems posed by fundamental corporate changes. Those outside the web of contracts that make up modern, publicly held firms may be in a weaker position to protect themselves froin exploitation than fixed claimants. This part of the Article considers their interests.

When U.S. Steel decided to close its plants in Youngstown, Ohio, the United Steel Workers claimed that the closings were prohibited because "a property right [had] arisen from the long-established relation between the community of the 19th Congressional District and Plaintiffs [the United Steel Workers] on the one hand, and Defendant [U.S. Steel], on the other."89 The Sixth Circuit expressed sympathy for this position, 90 but declined to grant a new property interest to the community;

might be better off as a group by agreeing to refrain from disrupting their work by searching for new jobs, but as individuals they clearly are better off if they can find a ney job equivalent to their old ones. Thus, agreeing not to be notified of a plant closing may benefit workers by mitigating the collective-action problem they face when they receive notification.

89. Local 1330, United Steel Workers v. United States Steel Corp, 631 F.2d 1264, 1280 (6th Cir. 1980) (citing plaintiff's complaint).

90. Id. The Sixth Circuit also quoted the district judge's statement that "United States Steel should not be permitted to leave the Youngstown area after drawing from the lifeblood of the convmunity for so many years." Id. at 1266. 
the court reluctantly concluded that "no authority for such a decision existed at either the state or national level." 1

Professor Joseph Singer argues vigorously that the Youngstown case was wrongly decided.92 $\mathrm{He}$ claims that the law often recognizes a rehance interest in property and that such an interest supports judicial allocation of a property right to communities and community groups that act in rehance on a firm's continued operation in their communities. If accepted, this argument could entitle hospitals, service organizations, and local governments, which have no preexisting contractual relationship with a firm, to coinpensation whenever a fundamental corporate change causes thein harm.

The argument has surface plausibility. For one thing, unlike the mdividuals and groups discussed in part II, the constituencies that Singer discusses lack contractual privity with firms undergoing fundamental corporate changes and may not be able to protect theniselves fron firms' opportunistic behavior. Again, the problem is that the relevant commumity groups make firm-specific investments. Corporate einployees require hospitals, churches, and schools, and firms require sewers, roads, and other capital improvenients. But all of these investinents are sometimes tailored to particular corporations. A local government might choose the location of a hospital, for example, to better serve a factory that has a large nuniber of industrial accidents. If the factory closes, and the community reconfigures to accommodate a different industry, the hospital may find itself unable to maintain its level of serviees. Similarly, different industries might give rise to different philanthropies. A coal mining operation might support a black lung chinc, and a brewery might support an alcohol treatinent center. Both the communities and the firms within then value the firm-specific capital investments that such service organizations require. If such organizations can be rendered useless at the whim of the corporations they support, then people will have less incentive to establish such organizations, and valuable social services will go unprovided.

As attractive as legal protection for these noncontracting organizations might seem, the law should not inandate such protection for at least three reasons. First, like the imposition of a plant-closing rule, the recognition of such a legal right would decrease investments in plants and equipment im jurisdictions that recognized such a right. Moreover, business firms would hesitate to support or recognize such organizations, fearing that such support would give rise to reliance interests. This reac-

91. Id.

92. Singer, supra note 1 , at 621 . 
tion would, of course, harm the very people that such a legal rule should protect. ${ }^{93}$

Second, these organizations can themselves protect any firm-specific investments they make. Local governments and philanthropies are unlikely to make firm-specific mvestments unless they receive compensation for them because, like other entities, such organizations have multiple demands on their resources. Put another way, corporations compete for the services of philanthropies. This competition results from the fact that supportive philanthropies and local government agencies enhance the profitability of the organizations they serve. Their activities can reduce firms' direct and indirect labor costs significantly, 94 and these benefits force firms who enjoy the services of such philanthropies to deal with them appropriately. Indeed, these organizations often provide health-related services and other support that corporations would otherwise feel compelled to provide. Thns, saying that these organizations have no contractual relationship with the firms they serve is misleading. The contractual relationship may be informal, but it exists nonetheless.

Presumably, government entities and philanthropies provide services to firms because they can do so most efficiently. For example, governments, because of their eminent domain power, are particularly well suited to providing roads and sewers. In contrast, the similar health care needs of several local busmesses may make it inost efficient for one specialized support orgamization to serve those businesses. Hospitals appear to fit this model especially well, because they tend to specialize their health care services to meet the needs of the commumities they serve. This structure of philanthropic support poses the danger that business firms enjoying the benefits of such support will free-ride on the generosity of their neighbors, since philanthropies generally cannot exclude the employees of firms that do not contribute their share of the cost of support services being provided. Philanthropic organizations in commumities where many similar industries exist will be especially vulnerable to such opportumistic behavior. In these communities, private hospitals will price their services to cover their costs, or local governments will establish public hospitals and tax businesses to avoid free-riding. Where freerider problems are not so acute, individual firms might vertically integrate services provided by outside organizations. In sum, philanthropies will structure themselves to eliminate frec-rider and firm-specific capital

93. See Shapiro, supra note 80 , at 560 .

94. Such organizations reduce employers' direct labor costs by enhancing the quality of life in the communities in which those employers operate. Employees will be willing to trade direct remuneration for improvement in quality of life. They reduce employers' indirect labor costs in a variety of ways, such as by lowering health care costs and employee absenteeism. 
investment problems, again illustrating how private ordering allows flexible responses that public regulation cannot provide.

The bargaining that takes place between state and local governments and business firms that are considering relocation shows low private ordering in this area works. Such negotiations often entail the exchange of specific promises by both parties and deinonstrate the degree to which third parties can deal effectively with the corporations they serve.

The third and perhaps most important reason not to grant property rights in business firms to local governments and philanthropies is that such a legal right would lead to opportunistic belravior by the organizatious providing services to corporations. If property rights would enable these organizations to extract payments froin corporations undergoing fundamental corporate changes, such organizations would have incentives to take actious that would help them "earn" such a property right. Such opportunistic behavior would harm corporations and workers alike and would exacerbate the disincentives to initial capital investments that legal recognition of a reliance interest im philanthropies and local governments creates. Obviously, not all philanthropies and local governinents would engage in such opportunistic behavior, but soine undoubtedly would. This behavior militates against the creation of a new property right where none appears needed.

\section{CONClusion}

On the surface, few issues of corporate law present as appealing a case for regulatory intervention as the effect of fundamental corporate changes on non-shareholder constituencies. These changes can profoundly disrupt the lives of everyone connected to the firms that experience them; indeed, corporate change seems a paradigm of corporate exploitation of innocent third parties.

This Article has studied the legitimate interests of affected groupsparticularly employees-who, compared to shareholders, appear to bear a disproportionate share of the costs of fundamental corporate changes while enjoying few, if any, of the econornic benefits of these changes. The Article has argued that the problems posed by fundamental corporate changes result from the fact that shareholders can use such changes to appropriate the firm-specific human capital investments of third parties, sucl as managers, workers, supphers, and customers. The debate about regulation of fundamental corporate changes thus focuses not on the possibility of third parties' exploitation, but on the question whether the private contracting process can protect such third parties' interests. This Article has argued not only that private contracting can give this protec- 
tion, but that it generates results that make the affected parties better off than if their rights were "protected" by regulatory intervention.

As discussed above, regulatory initiatives that attempt to do inore than simply enforce legitimate private agreements discourage investments, thus raising capital costs and slowing econonic growth. These rules also prevent private parties from customizing legal rules to meet their own needs, and force third parties dealing with corporations to accept a form of compensation or risk-taking that they may find less than optimal. For example, under a legal regime that "protects" employees from the effects of fundamental corporate changes, employees who prefer to obtain additional salary or pension benefits in exchange for statutorily iniposed protections would be made worse off.

Finally, granting non-shareholder constituencies a "reliance" property interest in corporate assets would prompt those parties to engage in strategic behavior in an effort to maximize the probability of acquiring such a property interest. This strategic behavior would benefit no one, but would impose costs on corporatious and a deadweight welfare loss on society.

For all of these reasons, the traditional common law rules of corporate governance, which provide that corporate directors have an exclusive obligation to maximize value for residnal claimants and which rely on the contracting process to protect the legitimate and iniportant interests of third parties, do not "exploit" non-shareholder constituencies. Rather, they best serve the interests of society as a whole. Measures that transfer control over fundamental corporate changes from shareholders to non-shareholders will injure both shareholders and the other constituencies that such measures seek to benefit. In the end, a straightforward approach to fundamental corporate change, one that protects the rights and interests of residual claimants, is still entitled to respect within our legal systern. 